\title{
Analisis Laporan Keuangan dalam Menilai Kesehatan Kinerja Keuangan Perusahaan Pada PT. Bank Perkreditan Rakyat (BPR) Jateng Tahun 2013-2017
}

\author{
Haninditya Nurullasari*, Nanang Yusroni dan Ernawati Budi Astuti \\ Jurusan Akuntansi, Fakultas Ekonomi, Universitas Wahid Hasyim \\ *Email: hanindityasugihono@gmail.com
}

\begin{abstract}
This study aims to determine the level of soundness of the company's financial performance from PT. BPR in 2013-2017 using ratio analysis of capital, profitability and liquidity factors. The data analysis technique used is a quantitative descriptive analysis technique. Based on the results of data analysis and discussion shows that the financial health performance of PT. Central Java Rural Banks (BPR) in 2013-2017 viewed from the capital factor if calculated using the CAR ratio can be categorized as HEALTHY. When viewed from the profitability factor and calculated using the ROA ratio it is also categorized HEALTHY, but when seen the BOPO ratio of PT. Central Java Rural Bank in 2015-2017 is categorized as NOT HEALTHY because the resulting ratio is too high so it is inefficient. While the health level is seen from the liquidity factor of PT. Central Java Rural Bank is categorized as HEALTHY.
\end{abstract}

Keywords: Soundness, Capital Adequacy Ratio (CAR), Return On Assets (ROA), Operating Expenses Against Operating Income (BOPO), Cash Ratio, Loan to Deposit Ratio (LDR)

\begin{abstract}
Abstrak
Penelitian ini bertujuan untuk mengetahui tingkat kesehatan kinerja keuangan perusahaan dari PT. BPR Jateng Tahun 2013-2017 dengan menggunakan analisis rasio dari faktor permodalan, rentabilitas dan likuiditas. Teknik analisis data yang digunakan adalah teknik analisis deskriptif kuantitatif. Berdasarkan hasil analisis data dan pembahasan menunjukkan bahwa kesehatan kinerja keuangan PT. Bank Perkreditan Rakyat (BPR) Jateng pada tahun 2013-2017 dilihat dari faktor permodalan apabila dihitung dengan menggunakan rasio CAR dapat dikategorikan SEHAT. Jika dilihat dari faktor rentabilitas dan dihitung dengan menggunakan rasio ROA juga dikategorikan SEHAT, namun apabila dilihat rasio BOPO PT. Bank Perkreditan Rakyat Jateng tahun 2015-2017 dikategorikan TIDAK SEHAT karena rasio yang dihasilkan terlalu tinggi sehingga tidak efisien. Sedangkan tingkat kesehatan dilihat dari faktor likuiditas PT. Bank Perkreditan Rakyat Jateng dikategorikan SEHAT.
\end{abstract}

Kata Kunci : Tingkat Kesehatan, Capital Adequacy Ratio (CAR), Return On Assets (ROA), Beban Operasional Terhadap Pendapatan Operasional (BOPO), Cash Ratio, Loan to Deposit Ratio (LDR)

\section{PENDAHULUAN}

Bank Perkreditan Rakyat (BPR) saat ini semakin berkembang pesat dari perkotaan sampai ke pedesaan. Peran Bank Perkreditan Rakyat (BPR) tersebut merupakan salah satu cara untuk meningkatkan ekonomi masyarakat khusunya masyarakat pedesaan dan pengusaha kecil. Keberadaan Bank Perkreditan Rakyat (BPR) sangat membantu masyarakat dan pengusaha kecil dengan proses yang sangat mudah dan cepat, hal ini juga dapat menjadi solusi bagi masyarakat. Proses kredit yang relatif cepat, persyaratan lebih sederhana dan mengerti kebutuhan nasabah serta lokasi yang dekat dapat menjadikan Bank Perkreditan Rakyat (BPR) semakin diminati oleh masyarakat. Oleh karena itu, bank merupakan suatu lembaga yang sangat bergantung kepada kepercayaan nasabah tentunya harus terus menyempurnakan pelayanannya untuk dapat bersaing dengan banyaknya penyedia jasa keuangan lainnya.

Dalam mengukur kinerja atas keuangan, kondisi keuangan atas suatu perusahaan maka dapat dilakukan dengan menganalisis atau menganalisa laporan keuangan sehingga dapat memberikan pemahaman dan kekuatan kepada perusahaan. Menurut Hery (2015) dalam Rabuisa (2018), analisis laporan keuangan merupakan suatu proses dalam membedakan laporan keuangan kedalam 
unsurnya dan menelaah masing-masing dari unsur tersebut yaitu dengan suatu tujuan untuk memperoleh pemahaman yang baik dan tepat atas laporan keuangan itu sendiri.

Bank Perkreditan Rakyat (BPR) merupakan bank yang melaksanakan kegiatan usaha secara konvensional atau berdasarkan prinsip syariah. Dalam kegiatannya BPR tidak memberikan jasa dalam lalu lintas pembayaran. Dari definisi diatas dapat dilihat jika kegiatan dari Bank Perkreditan Rakyat jauh lebih sempit dibandingkan dengan Bank Umum. Bank Perkreditan Rakyat dibatasi oleh berbagai persyaratan, sehingga tidak dapat berbuat seleluasa Bank Umum. Keterbatasan kegiatan Bank Perkreditan Rakyat juga dikaitkan dengan misi pendirian Bank Perkreditan Rakyat itu sendiri. Kegiatan Bank Perkreditan Rakyat menghimpun dana dalam bentuk simpanan tabungan dan deposito serta menyalurkan dana dalam bentuk kredit investasi, modal kerja maupun perdagangan.

Dalam menghadapi persaingan yang ketat terkadang Bank Perkreditan Rakyat (BPR) memberikan kemudahan dan kelonggaran dalam pemberian kredit, seperti kecepatan proses pemutusan pemberian kredit dan kelonggaran aturan agunan. Kemudahan pemutusan pemberian kredit dapat berdampak pada adanya masalah kredit macet dan mengakibatkan Bank Perkreditan Rakyat (BPR) menjadi tidak sehat. Perkembangan sektor perbankan yang semakin pesat juga dapat berpengaruh terhadap performa Bank Perkreditan Rakyat (BPR) serta dapat meningkatkan resiko yang dihadapi oleh suatu bank. Hal tersebut mampu mendorong tidak terciptanya industri perbankan yang kuat apabila performa kinerja keuangannya menurun. Kinerja suatu perbankan dapat dinilai melalui analisis atas laporan keuangan bank.

Analisis laporan keuangan merupakan hasil terakhir dari sebuah proses akuntansi yang dapat memberikan informasi mengenai posisi keuangan, hasil usaha serta perubahan dalam posisi keuangan suatu perusahaan sehingga dapat dijadikan patokan untuk mengukur kesehatan kinerja keuangan suatu perusahaan perbankan. Pengukuran kesehatan kinerja keuangan perusahaan dapat dilakukan dengan menganalisis laporan keuangan dengan menggunakan perhitungan rasio capital, earning, dan liquidity. Perhitungan rasio tersebut merupakan salah satu cara untuk dapat mengevaluasi kesehatan kinerja maupun keadaan keuangan suatu perusahaan di masa lalu, sekarang maupun masa yang akan datang. Rasio-rasio tersebut dapat dihitung dengan didasari sumber data yang berasal dari laporan keuangan perusahaan perbankan.

Tabel 1. Perkembangan Hasil Usaha PT. Bank Perkreditan Rakyat (BPR) Jateng Tahun 2013-2017

\begin{tabular}{|l|l|l|l|}
\hline Tahun & \multicolumn{1}{|c|}{ Pendapatan } & \multicolumn{1}{|c|}{ Biaya-biaya } & \multicolumn{1}{c|}{ Laba Setelah Pajak } \\
\hline 2013 & $15.768 .488 .399,22$ & $12.867 .672 .051,70$ & $4.154 .871 .843,39$ \\
\hline 2014 & $22.464 .657 .400,12$ & $20.072 .362 .373,05$ & $4.680 .428 .554,90$ \\
\hline 2015 & $24.368 .473 .403,17$ & $23.639318 .397,77$ & $3.885 .597 .552,05$ \\
\hline 2016 & $24.588 .891 .311,75$ & $24.571 .219 .814,45$ & $3.636 .824 .862,20$ \\
\hline 2017 & $25.426 .371 .868,77$ & $26.015 .590 .551,01$ & $3.501 .103 .631,85$ \\
\hline
\end{tabular}

Sumber : Laporan Tahunan PT. BPR Jateng Tahun 2013-2017

Sistem penilaian tingkat kesehatan Bank Perkreditan Rakyat mengacu pada Surat Keputusan Direksi Bank Indonesia Nomor 30/12/Kep/Dir/1997 tentang Tata Cara Penilaian Tingkat Kesehatan Bank Perkreditan Rakyat. Rasio keuangan untuk mengukur tingkat kesehatan bank dalam perbankan sering disebut rasio keuangan atas analisa CAMEL. Analisa CAMEL merupakan analisa terhadap pos Capital, Assets, Management, Earning, Liquidity. Analisa tersebut terdiri dari rasio-rasio seperti CAR, ROA, ROE, BOPO, Cash Ratio, LDR. Analisa menggunakan rasio keuangan yang ada dalam CAMEL akan memberikan informasi yang memadai mengenai tingkat kesehatan suatu perbankan serta dapat memudahkan manajemen dalam mengawasi bisnis perbankan yang berpegang teguh pada SOP dan Peraturan Bank Indonesia.

Analisis laporan keuangan yang digunakan peneliti untuk menilai kesehatan kinerja keuangan dengan melakukan perhitungan Capital Adequacy Ratio (CAR), Return On Assets (ROA), Biaya Operasional Terhadap Pendapatan Operasional (BOPO), Cash Ratio dan Loan to Deposit Ratio (LDR). Perhitungan rasio-rasio tersebut dapat dilihat dari total pendapatan, biaya- 
biaya serta laba suatu perusahaan. Sehingga berdasarkan data yang diperoleh dari laporan keuangan Bank Perkreditan Rakyat (BPR) Jateng diatas, dapat dilihat jika total pendapatan yang mengalami peningkatan juga diikuti dengan total biaya-biaya yang meningkat pula, jadi hal tersebut dapat berpengaruh terhadap rasio profitabilitas/ rentabilitas perusahaan. Dari data diatas dapat mempengaruhi rasio likuiditas maupun rasio rentabilitas perusahaan. Dilihat dari laba setelah pajak yang ditunjukkan dalam data diatas, laba yang dihasilkan PT. Bank Perkreditan Rakyat (BPR) Jateng tahun 2013-2017 juga mengalami penurunan, maka hal tersebut dapat mempengaruhi rasio rentabilitas.

Berdasarkan uraian diatas maka penulis tertarik untuk menganalisis laporan keuangan dalam menilai kesehatan kinerja keuangan perusahaan pada pt. bank perkreditan rakyat (BPR) jateng tahun 2013-2017.

\section{METODE PENELITIAN}

Jenis penelitian yang digunakan dalam penelitian ini adalah penelitian komparatif dengan menggunakan metode penelitian deskriptif kuantitatif. Penelitian komparatif yaitu penelitian dengan cara melakukan perbandingan kinerja Bank Perkreditan Rakyat (BPR) Jateng periode 20132017 dengan menggunakan analisis terhadap rasio keuangan. Rasio- rasio keuangan tersebut diantaranya Capital Adequacy Ratio (CAR), Return On Assets (ROA), Beban Operasional Terhadap Pendapatan Operasional (BOPO), Cash Ratio dan Loan to Deposit Ratio (LDR).

Analisis berdasarkan rasio-rasio keuangan bank meliputi :

1. Capital Adequacy Ratio (CAR)

$$
\mathrm{CAR}=\frac{\text { Modal }}{\text { Aktiva Tertimbang Menurut Risiko }} \times 100 \%
$$

2. Return On Assets (ROA)

$$
\frac{\text { Laba Sebelum Pajak }}{\text { Total Aset }} \times 100 \%
$$

3. $\mathrm{BOPO}$

$$
\mathrm{BOPO}=\frac{\text { total beban operasional }}{\text { total pendapatan operasional }} \times 100 \%
$$

4. Cash Ratio

$$
\text { Cash Ratio }=\frac{\text { Aset Lancar }}{\text { Kewajiban Lancar }} \times 100 \%
$$

5. Loan To Deposit Ratio (LDR)

$$
\mathrm{LDR}=\frac{\text { Jumlah Kredit yang Diberikan }}{\text { Dana Pihak Ketiga }} x 100 \%
$$

Indikator penilaian dan bobot kesehatan kinerja perusahaan diatur dalam SK Dir BI No 30/12/Kep/Dir/1997 Tentang Tata Cara Penilaian Tingkat Kesehatan Bank Perkreditan Rakyat.

\section{PEMBAHASAN}

Berdasarkan analisis data diatas maka dapat diketahui hasil perhitungan rasio CAR dari jumlah modal dan Aktiva Tertimbang Menurut Risiko (ATMR) tahun 2013 sampai 2017. Rasio CAR PT. Bank Perkreditan Rakyat Jateng Tahun 2013-2017 mengalami peningkatan dan penurunan setiap tahunnya. Meskipun mengalami peningkatan dan penurunan PT. Bank Perkreditan Rakyat Jateng tetap mampu menjaga posisi CAR diatas standar minimum yang ditetapkan dalam Surat Keputusan Direksi Bank Indonesia Nomor 30/12/KEP/DIR/1997 yaitu sebesar 8\%. Rasio CAR yang dihasilkan PT. Bank Perkreditan Rakyat Jateng dari tahun 2013-2017 berturut-turut adalah 14,51\%,14,07\%,13,54\%, 14,71\%, dan 13,30\%. Setelah diperoleh rasio CAR PT. Bank Perkreditan Rakyat Jateng Tahun 2013-2017 dapat diketahui juga Nilai Kredit Komponen CAR selama tahun 2013- 2017 yaitu sebesar 146,11; 141,78; 136,48; 148,19 dan 134,09. Akan tetapi dari Nilai Kredit Komponen yang dihasilkan tersebut maksimal yang ditetapkan 100, sehingga Nilai Kredit Komponen CAR yang diakui adalah 100.

Sedangkan untuk bobot Nilai Kredit Faktor CAR menurut peraturan yang berlaku sebesar 30\%. Bobot faktor CAR tersebut dikalikan dengan Nilai Kredit Komponen yang diakui sebesar 100. Dengan demikian diperoleh Nilai Kredit Faktor CAR/ Kewajiban Penyediaan Modal 
Minimum Bank (KPMM) PT. Bank Perkreditan Rakyat Jateng Tahun 2013-2017 yaitu 30. Berdasarkan kriteria penilaian dimana rasio CAR berada diatas $8 \%$ maka rasio CAR PT. Bank Perkreditan Rakyat Jateng dapat dikategorikan sehat, semakin besar rasio CAR yang dimiliki oleh bank akan semakin baik karena bank mampu menyediakan modal yang besar .

Rasio rentabilitas digunakan untuk mengukur tingkat efisiensi usaha dan profitabilitas yang dicapai oleh perusahaan. Penilaian terhadap faktor rentabilitas berdasarkan laporan posisi keuangan dan laporan laba rugi, laba sebelum pajak dan total aset PT. Bank Perkreditan Rakyat Jateng Tahun 2013-2017 tidak stabil karena mengalami peningkatan dan penurunan setiap tahunnya. Meskipun terjadi penurunan dan peningkatan setiap tahunnya, rasio ROA PT. Bank Perkreditan Rakyat Jateng Tahun 2013-2017 tetap diatas standar minimum yang ditetapkan. Rasio ROA yang dihasilkan PT. Bank Perkreditan Rakyat Jateng Tahun 2013-2017 berturut-turut adalah 6,15\%, 5,22\%, 4,18\%, 4,03\% dan 3,72\%. Untuk Nilai Kredit Komponen Rasio ROA PT. Bank Perkreditan Rakyat Jateng Tahun 2013-2017 yang dihasilkan adalah 410,10; 348,53; 278,96; 268,76 dan 248,34. Seperti halnya Nilai Kredit Komponen rasio yang lain, Nilai Kredit Komponen Rasio ROA yang diakui adalah 100. Sedangkan untuk penilaian bobot faktor ROA sebesar 5\%, Nilai Kredit Faktor ROA PT. Bank Perkreditan Rakyat Jateng Tahun 2013-2017 sebesar 5. Berdasarkan kriteria penilaian Rasio ROA menurut Surat Keputusan Direksi Bank Indonesia Nomor 30/12/KEP/DIR/1997 PT. Bank Perkreditan Rakyat Jateng Tahun 2013-2017 dilategorikan dalam kelompok sehat karena semakin tinggi rasio ROA menunjukkan bahwa bank mampu dengan baik mengelola aset yang dimiliki untuk menghasilkan laba.

Hasil penilaian pada analisis BOPO PT. Bank Perkreditan Rakyat Jateng Tahun 2013-2017 dapat dilihat untuk rasio BOPO tahun 2013 dan 2014 dikategorikan sehat karena rasio BOPO yang dihasilkan dibawah standar penilaian yaitu sebesar $81,60 \%$ dan $89,35 \%$. Sedangkan rasio BOPO tahun 2015 sampai 2017 dikategorikan tidak sehat karena rasio BOPO yang dihasilkan diatas standar yaitu sebesar 97\%, 99,92\% dan 102,31\%. Rasio BOPO ini merupakan rasio perbandingan biaya operasional dengan pendapatan operasional, maka semakin rendah tingkat rasio BOPO berarti semakin baik kinerja manajemen karena lebih efisien dalam menggunakan sumber daya yang ada dalam perusahaan. Untuk Nilai Kredit Komponen Rasio BOPO berdasarkan peraturan yang berlaku maksimal adalah 100. Sehingga Nilai Kredit Komponen Rasio BOPO PT. Bank Perkreditan Rakyat Jateng Tahun 2013 dan 2014 yang diakui adalah 100 dan untuk tahun 20152017 berturut-turut adalah 37,40; 0,89 dan 0. Nilai Kredit Rasio BOPO Tahun 2017 sama dengan nol karena menurut ketentuan yang berlaku apabila rasio BOPO lebih dari atau sama dengan $100 \%$ Nilai Kreditnya ditetapkan 0. Sedangkan untuk Nilai Kredit Faktor penilaian bobot rasio BOPO yang ditetapkan sebesar 5\%.

Rasio likuiditas digunakan untuk mengukur kemampuan bank dalam memenuhi kewajibankewajiban jangka pendeknya atau kewajiban yang sudah jatuh tempo. Penilaian terhadap faktor likuiditas ini didasarkan pada Cash Ratio dan Loan to Deposit Ratio. Berdasarkan laporan keuangan PT. Bank Perkreditan Rakyat Jateng Tahun 2013-2017, total aset lancar dan kewajiban lancar terus mengalami peningkatan meskipun sempat mengalami penurunan pada tahun 2016. Cash Ratio PT. Bank Perkreditan Rakyat Jateng Tahun 2013-2017 berturut-turut adalah 114,54\%; 112,655; 112,02\%; 110,78\% dan 110,107\%. Berdasarkan perhitungan tersebut Cash Ratio PT. Bank Perkreditan Rakyat Jateng masih mampu menjaga Cash Ratio untuk tetap berada diatas standar kriteria penilaian. Nilai Kredit Komponen Cash Ratio tahun 2013-2017 yang dianggap sebesar 100 karena yang dihasilkan lebih dari 100. Untuk Nilai Kredit Faktor Cash Ratio bobot penilaiannya sebesar 5\% sehingga Nilai Kredit Faktor PT. Bank Perkreditan Rakyat Jateng Tahun 2013-2017 adalah 5. Penilaian PT. Bank Perkreditan Rakyat Jateng Tahun 2013-2017 dapat dikategorikan sehat karena masih mampu menjaga Cash Ratio diatas 4,05\%.

Loan to Deposit Ratio (LDR) PT. Bank Perkreditan Rakyat Jateng tahun 2013 dikategorikan tidak sehat karena rasio LDR yang dihasilkan mencapai 104,16\%. Hal tersebut juga dapat disebabkan oleh kredit yang diberikan lebih besar daripada dana yang diterima oleh bank. Sedangkan untuk LDR tahun 2014-2017 dikategorikan SEHAT karena rasio LDR yang dihasilkan tetap berada dibawah 94,75\% sesuai dengan kriteria penilaian LDR menurut Surat Keputusan Direksi Bank Indonesia Nomor 30/12/KEP/DIR/1997. Untuk Nilai Kredit Komponen LDR yang ditetapkan maksimal adalah 100. Sehingga untuk Nilai Komponen Kredit yang diatas 100 tetap 
diakui 100. Nilai Kredit Komponen LDR PT. Bank Perkreditan Rakyat Jateng yang masih dibawah 100 dihasilkan oleh tahun 2013 dan 2016. Sedangkan untuk Nilai Kredit Faktor LDR bobot penilaian yang berlaku sebesar 5\%. Cara pehitungan Nilai Kredit Faktor LDR sama halnya dengan rasio-rasio yang lain yaitu dengan mengalikan Nilai Kredit Komponen dengan Bobot Penilaian.

\section{KESIMPULAN}

Tingkat kesehatan PT. Bank Perkreditan Rakyat Jateng Tahun 2013-2017 dilihat dari faktor permodalan (Capital) rasio CAR termasuk dalam kategori Sehat karena rasio CAR yang dihasilkan lebih dari 8\%. Rasio CAR PT. Bank Perkreditan Rakyat Jateng Tahun 2013-2017 berturut-turut adalah $14,51 \%, 14,07 \%, 13,54 \%, 14,71 \%$ dan 13,30\%. Sehingga kesehatan kinerja keuangan PT. Bank Perkreditan Rakyat Jateng Tahun 2013-2017 dilihat dari faktor permodalan dikataegorikan Sehat.

Tingkat kesehatan bank pada PT. Bank Perkreditan Rakyat Jateng dilihat dari faktor rentabilitas (Earnings), berdasarkan ROA yang dihasilkan dari tahun 2013-2017 PT. Bank Perkreditan Rakyat Jateng dapat dikategorikan SEHAT. Rasio perhitungan ROA selama 5 tahun selalu berada diatas $1,22 \%$ dan berturut-turut adalah $6,55 \%, 5,22 \%, 4,18 \%, 4,03 \%$ dan $3,72 \%$. Hasil perhitungan BOPO PT. Bank Perkreditan Rakyat Jateng tahun 2013-2017 adalah 81,60\%, 89,355, 97\%, 99,92\% dan 102,31\%. Dapat dilihat jikarasio BOPO tahun 2013 dan 2014 dikategorikan Sehat, sedangkan untuk tahun 2015-2017 dikategorikan tidak sehat karena rasio BOPO yang dihasilkan semakin meningkat. Sehingga dari faktor rentabilitas ROA bank diakategorikan Sehat sedangkan untuk menjaga rasio BOPO bank harus selalu menjaga tingkat efisiensi dalam melakukan kegiatan operasinya. Kesehatan Kinerja Keuangan PT. Bank Perkreditan Rakyat Jateng Tahun 2013-2017 dilihat dari faktor rentabilitas ROA dikategorikan Sehat.

Tingkat kesehatan bank pada PT. Bank Perkreditan Rakyat Jateng dilihat dari faktor likuiditas (Liquidity), berdasarkan Cash Ratio PT. Bank Perkreditan Jateng Tahun 2013-2017 bank dapat dikategorikan sehat. Karena Cash Ratio PT. Bank Perkreditan Rakyat Jateng mampu berada diatas $4,05 \%$ dan berturut-turut adalah $114,54 \%, 112,65 \%, 112,02 \%, 110,78 \%, 110,107 \%$. Hasil perhitungan rasio LDR pada tahun 2013 PT. Bank Perkreditan Rakyat Jateng dikategorikan tidak sehat karena rasio yang dihasilkan terlalu tinggi yaitu mencapai $104,16 \%$. Hal tersebut dapat disebabkan oleh pemberian kredit lebih dari dana yang diterima. Sedangkan rasio LDR dari tahun 2014-2017 dapat dikategorikan SEHAT karena masih berada pada kisaran predikat sehat yaitu sebesar 89\% s/d 93,75\%. Sehingga Kesehatan Kinerja Keuangan PT. Bank Perkreditan Rakyat Jateng Tahun 2013-2017 dilihat dari faktor likuiditas Cash Ratio dan Loan to Deposit Ratio dikategorikan SEHAT.

Secara keseluruhan tingkat kesehatan bank PT. Bank Perkreditan Rakyat Jateng Tahun 2013 dan 2014 dilihat dari faktor permodalan, rentabilitas dan likuiditas mengalami peningkatan. Akan tetapi untuk tahun 2015-2016 kesehatan kinerja keuangan PT. Bank Perkreditan Rakyat Jateng dilihat dari faktor permodalan, rentabilitas dan likuiditas mengalami penurunan secara terus menerus. Sedangkan di tahun 2017 penilaian kesehatan kinerja keuangan PT. Bank Perkreditan Rakyat Jateng dilihat dari faktor permodalan, rentabilitas dan likuiditas mengalami kenaikan meskipun sebesar 0.724 .

Saran terhadap bank harus dapat memperhatikan keakuratan posisi keuangan dan kinerja bank yang tercantum dalam laporan posisi keuangan dan laporan laba rugi, kemudian bank harus selalu memperhatikan fluktuasi yang terjadi agar tidak terjadi penurunan yang terlalu jauh yang dapat menyebabkan perusahaan tidak sanggup menyelesaikan permasalahan keuangan. Bank harus selalu memperhatikan tingkat efisiensi kemampuan bank dalam melakukan kegiatan operasinya sehingga bank harus dapat mengimbangi dan mengelola pendapatan dan biaya operasional agar dapat mencapai efisiensi kinerja keuangan yang baik. Akan lebih baik apabila bank harus mengurangi penggunaan biaya operasional dan terus meningkatkan pendapatan operasional.

\section{DAFTAR PUSTAKA}

Brigham, 2013, Dasar-Dasar Manajemen Keuangan, Salemba Empat

Buku Saku Standar Pelayanan BPR Jateng 
Jacob, 2013, “Analisis Laporan Keuangan Dengan Menggunakan Metode CAMEL Untuk menilai Tingkat Kesehatan Perbankan”, Jurnal EMBA, Vol. 1 No.3

Kasmir, 2012, Bank dan Lembaga Keuangan Lainnya, Raja Grafindo Persada, Jakarta

Laporan Tahunan PT. Bank Perkreditan Rakyat (BPR) Jateng

Lina, dkk, 2016, "Analisa Laporan Keuangan Untuk Menilai Kinerja Keuangan Pada PT. BPR Sriekaya Sidoarjo," Jurusan Akuntansi, Fakultas Ekonomi Universitas Bhayangkara Surabaya

Rabuisa, dkk, 2018, “ Analisis Laporan Keuangan Dalam Menilai Kinerja Keuangan Perusahaan Pada Bank Perkreditan Rakyat Dana Raya Manado,” Jurnal Riset Akuntansi Going Concern, Vol. 13, No. 02

Lianawati, dkk, 2016, "Penilaian Kesehatan Bank Perkreditan Rakyat (BPR) Berdasarkan Surat Keputusan Direksi Bank Indonesia Nomor 30/12/KEP/DIR Tahun 1997 pada PT. BPR Artha Pamenang Pare," Jurnal Administrasi Bisnis (JAB), Vol. 30 No. 1

Modul Perbankan PT. Bank Perkreditan Rakyat (BPR) JatengOttay, 2015, "Analisis Laporan Keuangan Untuk Menilai Kinerja Keuangan Pada PT. BPR Citra Dumoga Manado", Jurnal EMBA, Vol. 3 No. 1

Prakoso, dkk, 2017, "Analisis Metode Camel dan Pearls untuk menilai Tingkat Kesehatan BPR di Kota Bontang," Jurnal Akuntabel, Vol. 14, no. 2

Rabuisa, dkk, 2018, “ Analisis Laporan Keuangan Dalam Menilai Kinerja Keuangan Perusahaan Pada Bank Perkreditan Rakyat Dana Raya Manado,” Jurnal Riset Akuntansi Going Concern, Vol. 13, No. 02

Soemarso, 2004, Akuntansi Suatu Pengantar, Salemba Empat, Yogyakarta

Subramanyam, Edisi 10, Analisis Laporan Keuangan, Salemba Empat, Yogyakarta

Sunardi, 2018, "Analisis Kesehatan Bank Pada Bank BPR Sabee Meusampee Kota Lhokseumawe (2012-2015)," Jurnal Akuntansi dan Pembangunan, Vol. 4, No. 01

Sugiyono, 2008, Metode Penelitian Kuantitatif, Kualitatif dan R\&D, Alfabeta, Bandung

Surat Keputusan Direksi Bank Indonesia No. 30/12/KEP/DIR/1997 tentang "Tata Cara Penilaian Tingkat Kesehatan Bank Perkreditan Rakyat".

https://www.ojk.go.id (diakses 19/3/2019 19.45)

https://www.jurnal.id (diakses 30/4/2019 20:25)

https://www.bi.go.id (diakses 3/8/2019 18:30) 